Kurylo, B. 2021. Counter-populist performances of (in)security: Feminist resistance in the face of right-wing populism in Poland. Review of International Studies: 1-20. https://doi.org/10.1017/S0260210521000620

\title{
Counter-populist performances of (in)security: Feminist resistance in the face of right-wing populism in Poland
}

\begin{abstract}
IR scholarship has recently seen a burgeoning interest in the right-wing populist politics of security, showing that it tends to align with the international ultraconservative mobilisation against 'gender ideology'. In contrast, this paper investigates how local feminist actors can resist right-wing populist constructions of (in)security by introducing counter-populist discourses and aesthetics of security. I analyse the case of Poland, which presents two competing populist performances of (in)security: the Independence March organised by right-wing groups on Poland's Independence Day and the Women's Strike protests against the near-total ban on abortion. The paper draws on Judith Butler's theory of the performative politics of public assembly, which elucidates how the political subject of 'the people' can emerge as bodies come together to make security demands through both verbal and non-verbal acts. I argue that the feminist movement used the vehicle of populist performance to subvert the exclusionary constructions of (in)security by right-wing populists. In the process, it introduced a different conception of security in the struggle for a 'livable life'. The study expands the understanding of the relationship between populism, security and feminism in IR by exploring how the populist politics of security is differently enacted by everyday agents in local contexts.
\end{abstract}

Keywords: Feminism; Judith Butler; Performance; Poland; Populism; Security 


\section{Introduction}

Recently, there has been a global surge in right-wing populist parties and movements that mobilise the discourses of insecurity and the 'threatening Other' to establish their political dominance. The right-wing populist security politics comes in conjunction with international anti-gender mobilisation involving religious fundamentalist and nationalist groups in civil society. Right-wing populists tend to depict themselves as courageous defenders of 'the people' against 'gender ideology' propagated by global liberal elites. ${ }^{1}$ Drawing on these security discourses, populists have pushed for various anti-gender equality policies. Sexual and reproductive rights have been under attack in the United States, Brazil, Italy, Sweden, Hungary and Poland. Given these developments, it is unsurprising that IR scholars have tended to view the relation between populism, security and gender in a negative light. With populism being granted the status of a 'globalising' concept, the assumption of its incompatibility with feminist politics seems to have come close to gaining universal validity. ${ }^{2}$ Nonetheless, this paper refutes the idea that populism has an unchanging nature that is antithetical to feminist goals by examining the case of populist feminism in Poland. Looking at how the populist politics of security is translated locally is necessary to widen the understanding of populism and feminist resistance in international politics.

The study is driven by the observation that feminist movements have increasingly sprung up in many parts of the world to defend women's rights and democratic

${ }^{1}$ Elżbieta Korolczuk and Agnieszka Graff, "Gender as "ebola from Brussels": The anticolonial frame and the rise of illiberal populism', Signs, $43: 4$ (2018), pp. 797-821.

${ }^{2}$ Bice Maiguashca, 'Resisting the "populist hype": A feminist critique of a globalising concept', Review of International Studies, $45: 5$ (2019), pp. 768-785 (p. 768). Christine Agius, Annika B. Rosamond and Catarina Kinnvall, 'Populism, ontological insecurity and gendered nationalism: Masculinity, climate denial and Covid-19', Religion \& Ideology, 21:4 (2020), pp. 432-50. 
institutions against the worldwide rise of radical right-wing populism. ${ }^{3}$ In the United States, the imperative to resist Donald Trump's political regime catalysed a large-scale feminist mobilisation in the form of women's marches attended by millions of people. $\mathrm{Ni}$ Una Menos, a Latin American intersectional feminist grassroots movement, has also positioned itself in opposition to the onset of right-wing populism in the Americas. Finally, in Poland, a feminist pro-choice movement galvanised in response to the attempts to tighten the already strict abortion law by the currently ruling party, Law and Justice (Prawo i Sprawiedliwość, PiS). Feminist movements constitute one of the most powerful forces of resistance in the face of right-wing populist exclusionary discourses of security. However, feminist resistance need not always be simply opposed to and destructive of (right-wing) populism. Some instances of feminist resistance can turn into what Lilja calls 'constructive resistance', producing new subjectivities, narratives and expressions of resistance. ${ }^{4}$ The interest of this paper lies in the capacity of feminist agents on the ground to imaginatively recast the relationship between populism and security.

Focusing on the case of Poland, the paper investigates how a pro-choice feminist movement tried to subvert right-wing populist constructions of (in)security by introducing alternative discourses and aesthetics of security. I argue that feminist resistance can inaugurate a counter-populist politics of security, using some aspects of populism to establish 'the feminist people' as an alternative subject of security. To this end, I first examine what in the Polish context appears to be the prime example of a rightwing populist enactment of (in)security - the March of Independence that takes place on

\footnotetext{
${ }^{3}$ Sanja Bojanic, Mónica C. Abadía and Valentina Moro, 'Feminist responses to populist politics', European Journal of English Studies, 25:2 (2021), pp. 113-32. Agnieszka Graff, 'Angry women: Poland's Black Protests as "populist feminism", in Gabriele Dietze and Julia Roth (eds), Right-Wing Populism and Gender (Bielefeld: transcript-Verlag, 2020), pp. 231-50. Julia Roth, Can Feminism Trump Populism? Right-Wing Trends and Intersectional Contestations in the Americas (New Orleans: University of New Orleans Press, 2021).

${ }^{4}$ Mona Lilja, 'Pushing resistance theory in IR beyond "opposition": The constructive resistance of the \#MeToo movement in Japan', Review of International Studies, (2021), pp. 1-22.
} 
National Independence Day. Over the past decade, the march has been appropriated by right-wing groups that use it as a platform for asserting and securing the identity of 'the people' against its enemies. My curiosity about the aesthetic dimension of populism is consistent with the performative approach to populism. Populism is accordingly defined here as a performative enactment of the collective political subject of 'the people' against 'the elite', which tends to entail collective embodied performances of 'us in danger'. Using the performative approach to populism as its point of departure, the paper turns to Judith Butler's work to understand the role that public assemblies play in the performative self-constitution of 'the people in danger'.

Drawing on this theoretical framework, the focus of my contribution is on the populist feminist performances of (in)security enacted during the All-Poland Women's Strike of 2020-1 against the near-total ban of abortion. I consider the Polish pro-choice movement to be a case of populist feminism for three main reasons. First, its participants tend to present themselves as 'ordinary women' and speak in the name of and for 'the people'. ${ }^{5}$ Second, they frequently articulate the people-versus-elite dichotomy. ${ }^{6}$ Lastly, as will be illustrated later, the movement is characterised by a performative enactment of 'us in danger', exhibiting aesthetic aspects that are deliberately subversive of the dominant 'elitist' aesthetic of security. Here, it is necessary to note that I view populism as a normatively ambivalent phenomenon that, depending on the context, can be both a threat to and a corrective for democracy and have both exclusionary and inclusionary features. ${ }^{7}$ The study is based on written, spoken and visual data collected through social media research, including speeches, social media posts, slogans, images, memes, posters,

${ }^{5}$ Jenny Gunnarsson Payne, "Women as "the people": Reflections on the Black Protests as a counter-force against right-wing and authoritarian populism', Baltic Worlds, XIII:1 (2020), pp. 6-20. Graff, 'Angry women'.

${ }^{6}$ Ibid.

${ }^{7}$ Cas Mudde and Cristobal R. Kaltwasser, 'Populism and (liberal) democracy: A framework for analysis', in Cas Mudde and Cristobal R. Kaltwasser (eds), Populism in Europe and the Americas: Threat or Corrective for Democracy? (Cambridge: Cambridge University Press, 2012), pp. 1-26. 
placards, artworks and videos. I also draw on semi-structured interviews with members of right-wing groups ( 8 interviews) and pro-choice groups (20 interviews) conducted in July 2019 and between January and June $2021 .^{8}$

The analysis proceeds in six moves. First, I explain the benefits of the performative approach to populism and identify the gaps that my contribution seeks to address. The following section outlines Butler's theory of embodied and plural performativity that will serve as a framework for expounding the role of public assembly in the populist construction of (in)security. ${ }^{9}$ The third section looks at how the Independence March functions as a platform for enacting the right-wing populist discourse of ontological security. The fourth section is dedicated to the pro-choice movement: what makes it populist and the embodied performances that animated the construction of 'the feminist people'. Thereafter, I examine the aesthetic of security displayed by the Women's Strike demonstrations and analyse how it sought to unsettle the right-wing populist security imaginaries. In the final section, I conclude that Butler's concepts of 'precarity' and 'livable life' capture the logic of (in)security that has driven the feminist struggle for reproductive rights in Poland.

The paper contributes to the nascent yet fast-growing literature in IR on the relationship between populism and the politics of (in)security, which suffers from several shortcomings. ${ }^{10}$ First, while the verbal security utterances of populist leaders are wellstudied, little is known about how collective performances can 'speak' security, with the

\footnotetext{
${ }^{8}$ In order to preserve the anonymity of respondents, all of them have been assigned pseudonyms.

${ }^{9}$ Judith Butler, Notes Toward a Performative Theory of Assembly (Cambridge, MA: Harvard University Press, 2015).

${ }^{10}$ Daniel Béland, 'Right-wing populism and the politics of insecurity: How President Trump frames migrants as collective threats', Political Studies Review, 18:2 (2020), pp. 162-77. Alexandra Homolar and Ronny Scholz, 'The power of Trump-speak: Populist crisis narratives and ontological security', Cambridge Review of International Affairs, 32:3 (2019), pp. 344-64. Bohdana Kurylo, 'The discourse and aesthetics of populism as securitisation style', International Relations (2020), pp. 1-21. Thorsten Wojczewski, "Enemies of the people": Populism and the politics of (in)security, European Journal of International Security, 5:1 (2020), pp. 5-24.
} 
exception of Kurylo's work on the aesthetics of populist securitising style discussed later. ${ }^{11}$ This comes as a surprise, given the proliferating interest of the contemporary populism scholarship in the performative or aesthetic dimensions of populism. ${ }^{12}$ Moreover, most research has been preoccupied with the exhortations and actions of highprofile leaders, disregarding other actors involved in populist movements. Populist supporters are typically portrayed as reactive and incapable of mobilisation without a personalistic leader. Finally, the empirical focus of existing literature on populism in IR has fallen mainly on populism in its right-wing variant and Western contexts. Consequently, the understanding of how populists do security - and how the conception of security changes across different populist movements - has been somewhat narrowly centred on negative, exclusionary meanings and practices of security.

This study strengthens the knowledge of how populist actors construct (in)security by illuminating the role that embodied performance in public assembly plays in this process. By juxtaposing the ways in which two opposing camps of Polish civil society enact (in)security, the paper provides a lucrative starting point for thinking about the agency of so-called populist 'audiences' as opposed to the prevailing focus on the elites in populism studies. I also demonstrate that populism can interconnect with exclusionary and inclusionary logics of security alike, reinforcing the argument made by several security scholars that security and its normative value must be studied in context. ${ }^{13}$ Furthermore, the paper adds to the scholarship on social movements, enriching it with an

\footnotetext{
${ }^{11}$ Kurylo, 'Discourse and aesthetics of populism'.

${ }^{12}$ Benjamin Moffitt, The Global Rise of Populism: Performance, Political Style, and Representation (Stanford: Stanford University Press, 2016). Pierre Ostiguy, 'The socio-cultural, relational approach to populism', Partecipazione e Conflitto, 13:1 (2020), pp. 29-58. Julia Peetz, 'Legitimacy as a zero-sum game: Presidential populism and the performative success of the unauthorised outsider', Contemporary Political Theory, 19:4 (2019), pp. 642-62.

${ }^{13}$ Felix Ciută, 'Security and the problem of context: a hermeneutical critique of securitisation theory', Review of International Studies, 35:2 (2009), pp. 301-26. Jonna Nyman, 'What is the value of security? Contextualising the negative/positive debate', Review of International Studies, $42: 5$ (2016), pp. 821-39.
} 
empirical analysis of embodied power struggles in the Polish context. It highlights the significance of performance and performativity in populist 'dynamics of contention'. ${ }^{14}$ More broadly, the study contributes to the understanding of the global 'politics of resistance' as it emerges from below to challenge the hegemony of a particular vision of security propagated by the elites. ${ }^{15}$ I show that the rise of right-wing populism fosters counterforces that attempt to imaginatively reconstitute security and produce new subjectivities and referent objects. Security here appears as a site of contest between feminist movements and the state as well as between feminist and conservative groups within civil society.

\section{The performative approach to populism}

One of the most commonly used approaches to populism presents it as 'a thin-centred ideology that considers society to be ultimately separated into two homogeneous and antagonistic groups, "the pure people" and "the corrupt elite", and which argues that politics should be an expression of the volonté générale (general will) of the people'. ${ }^{16}$ This definition emphasises the centrality of a binary politics of confrontation to populism, its anti-establishment ethos and the proclivity of populist leaders to justify their actions with reference to the allegedly homogeneous will of 'the people'. The main shortcoming of the ideational approach, as Dean and Maiguashca point out, is that it posits 'a hierarchical relationship between political leaders and "the people", engineered and sustained primarily by enterprising professional politicians'. ${ }^{17}$ Maiguashca further

\footnotetext{
${ }^{14}$ Doug McAdam, Sidney Tarrow, and Charles Tilly, Dynamics of Contention (Cambridge: Cambridge University Press, 2001).

${ }^{15}$ Bice Maiguashca, 'Governance and resistance in world politics', Review of International Studies, 29 (2003), pp. 3-28. Juha Vuori, 'Contesting and resisting security in post-Mao China', in Thierry Balzacq (ed), Contesting Security: Strategies and Logics (Abingdon: Routledge, 2015), pp. 29-43.

${ }^{16}$ Mudde and Kaltwasser, 'Populism and (liberal) democracy', p. 8.

${ }^{17}$ Jonathan Dean and Bice Maiguashca, 'Did somebody say populism? Towards a renewal and reorientation of populism studies, Journal of Political Ideologies, 25:1 (2020), pp. 11-27 (p. 13).
} 
criticises the ideational approach for its 'hyper masculinist' representations of the (male) populist leader as 'a swaggering figurehead full of bravado, bluster and self-belief' ${ }^{18}$ In contrast, 'the people' are typically prescribed the role of the audience, whose agency is seen as merely reactive.

Another influential approach to populism understands it as a discourse. The key difference between the ideational and discursive approaches resides at an ontological level. The former treats 'the people' as a pre-existing constituency that seeks to resist 'the elite' that rule over them. In contrast, having a constructivist ontology, the discursive approach sees the political subjects of 'the people' and 'the elite' as constituted within an antagonistic relationship between two socio-political blocs: the marginalised 'underdogs' and 'the establishment'. In the words of Laclau and Mouffe, it is 'vis-à-vis oppressive forces' that 'a set of particularities establish relations of equivalence between themselves'. ${ }^{19}$ Populism springs up in the very act of the constitution of collective identities. Contrary to the prevailing normatively negative view of populism, Mouffe believes that 'left populism' could 'permit the radicalisation of democracy' by acting as a counter-hegemonic force against illiberal, authoritarian and right-wing regimes. ${ }^{20}$ While the discursive approach is useful for explaining the process through which the political subjectivity of 'the people' comes into being, it has been criticised for being too abstract and lacking methodological tools for 'analysing populism in more concrete terms' ${ }^{21}$

The final approach to populism examined here - and one which underpins this paper - conceptualises it as a style of doing politics or a mode of political performance. One of its leading representatives, Moffitt argues that populism takes the form of

\footnotetext{
${ }^{18}$ Maiguashca, 'Resisting the "populist hype", p. 776.

${ }^{19}$ Ernesto Laclau and Chantal Mouffe. Hegemony and Socialist Strategy: Towards a Radical Democratic Politics (London: Verso, 2001), p. xiii.

${ }^{20}$ Chantal Mouffe, For a Left Populism (London: Verso, 2018), p. 24.

${ }^{21}$ Mudde and Kaltwasser, 'Populism and (liberal) democracy', p. 7.
} 
'embodied, symbolically mediated performance made to audiences that are used to create and navigate the fields of power that comprise the political, stretching from the domain of government through to everyday life'. ${ }^{22}$ Its central features include an appeal to 'the people' versus 'the elite', 'bad manners' and the construction of crisis or threat. Rather than opposing the two aforementioned approaches to populism, the performative or sociocultural approach shares some of their features while also moving beyond them. It retains the focus on the leader from the ideational approach and does not challenge the peopleelite divide as a core element of populism. The performative approach also complements the Laclauian school with a more 'down-to-earth' focus by addressing the social and cultural conditions of the populist construction of identities. ${ }^{23}$

Insofar as this paper is concerned, the analytical purchase of the performative approach stems mainly from two original insights. First, it moves beyond the strictly linguistic-verbal discursive level and accounts for the non-verbal or aesthetic dimensions of populism, stressing an inextricable relation between content and form. Aesthetics defined as a contextually dependent conception of taste and beauty as expressed through actors' style, rhetoric and emotions - is an essential aspect of the populist mode of identification. By performing their speech acts in a particular way, populists seek to represent 'the people' and establish a specific kind of bond - both vertically, with the leader, and horizontally, among 'the people'. Ostiguy notably emphasises the role of 'low culture' performances in constituting and shaping popular identities seen in the use of informal, culturally popular elements in actors' styles of speech, dress and

${ }^{22}$ Moffitt, Global Rise of Populism, p. 38.

${ }^{23}$ Pierre Ostiguy, Francisco Panizza and Benjamin Moffitt, 'Introduction', in Pierre Ostiguy, Francisco Panizza and Benjamin Moffitt (eds), Populism in Global Perspective: A Performative and Discursive Approach (London: Routledge, 2020), pp. 1-18 (p. 2). 
comportment. ${ }^{24}$ In his words, "by re-presenting "people" as they (think) they are, [populists] constitute a certain kind of "people"". 25

Second, the performative approach creates an opening for a productive crossfertilisation between the studies of populism and security by highlighting the penchant of populists for the construction of insecurity. Moffitt was first to identify the performance of crisis as an essential feature of populism. ${ }^{26}$ Kurylo takes this assumption further by arguing that securitisation and populism are intertwined through the discourse of societal security that underpins the populist construction of 'the people'. Insofar as the discursive construction of the enemy at once threatens and helps to define the people, the identity of the latter is fundamentally precarious and must be constantly reasserted through new securitisation processes. Populism is thereby reimagined as a style of not only politics but also securitisation. Focusing on right-wing populism, Kurylo argues that it exhibits a distinctive aesthetic of security characterised by " "poor taste", sentimental ordinariness and deliberate obtuseness'. ${ }^{27}$ This aesthetic entices popular audiences by virtue of being transgressive of the 'elitist' aesthetic of security and the politically correct behaviour of 'rational' security speakers.

Building on the performative approach, this paper understands populism as a performative enactment of the collective political subject of 'the people' against the 'elite', which often entails embodied performances of 'us in danger'. At the same time, the paper seeks to fill three main gaps in the IR literature on populism. First, it moves beyond the fixation on the characteristics and actions of populist leaders. To challenge the view of populism as a top-down phenomenon, the paper explores the self-constitution of 'the endangered people' through concerted and embodied actions in public spaces.

\footnotetext{
${ }^{24}$ Ostiguy, 'Socio-cultural, relational approach to populism'.

${ }^{25}$ Ibid., p. 34.

${ }^{26}$ Moffitt, The Global Rise of Populism.

${ }^{27}$ Ibid., p. 16.
} 
Building on the work of Judith Butler, I investigate how new subjectivities and meanings of security come into being by means of public assembly. Second, the paper agrees that, in order to understand how populism works, scholars must attend to the role that 'security' plays in the constitution of 'the people'. Yet, the paper does not restrict itself to the fixed narrative framework of securitisation theory which offers limited resources for appreciating the contextual differences between various processes of (in)security construction. ${ }^{28}$ Instead, I study how two different populist movements perform (in)security, paying attention to the multivalent identities and meanings of security born in the process. Ultimately, the paper expands the knowledge of the populist aesthetic of security by examining it in action in a non-Western context. While the focus of previous research was on right-wing populism, I examine the aesthetic at the heart of the feminist counter-populist politics of security. Overall, the aim is to make the concept of populism more amenable to an empirical inquiry into unconventional populist actors in nonWestern contexts.

\section{Embodied performance and public assembly}

In studying how populist discourses of (in)security are performed and how subjectivities are constituted as a result, it is necessary to consider Judith Butler's work on the performative politics of public assembly. This paper takes Butler's idea of embodied and plural performativity as a framework for explaining the role of public assembly in the populist construction of (in)security. 'Public assemblies' - street protests, popular gatherings, strikes, rallies, marches and social media campaigns - are a central part of populist movements. The significance of public assemblies, where bodies move and speak together in public spaces, lies in the plural and embodied performances in which populist 'audiences' engage. The populist construction of 'the people' is an embodied act

\footnotetext{
${ }^{28}$ Annick Wibben, Feminist Security Studies: A Narrative Approach (London: Routledge, 2010).
} 
by the many, blurring the boundaries between performers and their audiences. The paper aims to understand what the assembly of bodies in public space signifies when considered in the context of the populist enactment of 'the endangered people'. This section outlines what it means to view the populist performance of (in)security through the lens of ' $a$ concerted bodily enactment, a plural form of performativity'. ${ }^{29}$

The performative capacity of populist performances lies in generating and displaying the plural subject that is being performed. Performativity can be broadly defined as 'acting, and in the acting, laying claim to the power one requires' in order to secure the conditions of one's existence. ${ }^{30}$ Contrary to representing a pre-existing identity, public assemblies are about performatively enacting and embodying the collective political subjectivity of 'the people' and, as I will later show, asserting its right to security. The performative politics of plural action is premised on the assumption that 'there is a collective acting without a preestablished collective subject', and 'the "we" is enacted by the assembly of bodies'. ${ }^{31}$ By visibly and publicly inserting their bodies into public space, participants in populist movements performatively produce a kind of 'we'. Taylor says that performance allows people to 'become seemingly not only of one mind but of one body', giving 'the illusion of ontological stability and coherence'. ${ }^{32}$ Focusing on populist performances in public assemblies allows us to capture a collectivity in the making through acts of self-designation and self-gathering. Performance is, therefore, a vehicle through which the participants in populist movements negotiate the boundaries of inclusion and exclusion in respect to the categories of 'the people' and security alike.

\footnotetext{
${ }^{29}$ Judith Butler, Performative Theory of Assembly, p. 8.

${ }^{30}$ Ibid., p. 58.

${ }^{31}$ Ibid., p. 5.

${ }^{32}$ Diana Taylor, 'Animating politics', in Adrian Kear and Jenny Edkins (eds), International Performance and Politics: Critical Aesthetics and Creative Practice (London: Routledge, 2013), pp. 84-95
} (p. 84). 
To say that performance is embodied is to place the body at the centre of analysis and focus on the particular aesthetic cultivated through verbal, sartorial and bodily practices. ${ }^{33}$ Butler argues that embodied and coordinated actions can signify something in excess of any particular demands vocalised during populist gatherings. The body embodies and concretises the populist narrative of the need to secure the 'endangered' body of 'the people' by physically showing up in public space. It is the concreteness displayed by the material, visible, touchable, feeling and vulnerable bodies that signifies something in excess of vocalised utterances in populist performances. With this, Butler notes that the body needs to be understood in relational terms to account for its dependency on other bodies and networks of support. ${ }^{34}$ As Rai explains, the body is socially embedded: 'it is positioned in relation to other bodies, which are historically specific, culturally framed and affect the ways in which bodies are viewed, represent/are represented, consent and resist' ${ }^{35}$ Rai also alerts us to the materiality of performing bodies - that is, 'to how are they marked by signs of power or marginality'. ${ }^{36}$ In short, one cannot comprehend the political meaning of the performing body without situating it in the network of relations in which it is embedded and through which it is produced.

By analysing populist performances as plural and embodied forms of performative action, we can broaden the understanding of how 'the endangered people' are constructed beyond the leader's speech to include the concerted action of a multitude of bodies. Butler writes that "the people" are not just produced by their vocalised claims, but also by the conditions of possibility of their appearance, and so within the visual field, and by their actions, and so as part of embodied performance'. ${ }^{37}$ Through the concerted actions of

\footnotetext{
${ }^{33}$ Jonathan Dean and Bice Maiguashca, 'Gender, power and left politics: From feminisation to “feministisation”, Politics \& Gender, 14:3 (2018), pp. 376-406 (p. 396).

${ }^{34}$ Butler, Performative Theory of Assembly, pp. 129-30.

${ }^{35}$ Shirin Rai, 'Political performance: A framework for analysing democratic politics', Political Studies, 63:5 (2015), pp. 1179-97 (p. 1183).

${ }^{36}$ Ibid.

${ }^{37}$ Butler, Performative Theory of Assembly, p. 19.
} 
bodies, 'the assembly is already speaking before it utters any words'. ${ }^{38}$ According to Butler, "the people" act by way of their collective silence or their ironic use of language: their humour and even their mockery take up and take over a language they seek to derail from its usual ends'. ${ }^{39}$ Overall, the production of 'the people' involves an interplay of linguistic and bodily performativity, as the body 'speaks' security through speech, gesture and even the very act of occupying space.

In explaining how performing bodies become able to 'speak' security, two other factors are important: matter and emotions. For Butler, the material environment (infrastructure and architecture) is part of the performance in the form of 'a collaborative actor'. ${ }^{40}$ Still, Butler argues that public space is not a pre-given 'thing', for different subjects do not have equal access to the square or the street. ${ }^{41}$ The public character of the material environment is produced through bodily public action, as specific groups seize and reconfigure the material environment. Lilja additionally highlights the performative force of emotions that 'bind figures together, which then creates the effect of a collective'. ${ }^{42}$ According to her, affects circulate between the bodies, which 'convey emotions to other bodies while receiving and forwarding intensities (emotions) themselves'. ${ }^{43}$ In manifesting themselves in and through political action, emotions can 'serve to shore up, or disrupt, established ways of thinking about and practising politics' ${ }^{44}$

Normatively speaking, the populist affective politics of security is neither an intrinsically positive nor an intrinsically negative phenomenon, though IR researchers

\footnotetext{
${ }^{38}$ Ibid., p. 9.

${ }^{39}$ Ibid., p. 157.

${ }^{40}$ Ibid., p. 127.

${ }^{41}$ Ibid., p. 71.

${ }^{42}$ Mona Lilja, 'Dangerous bodies, matter and emotions: Public assemblies and embodied resistance', Journal of Political Power, 10:3 (2017), pp. $342-52$ (p. 347).

${ }^{43}$ Ibid., pp. 346-7.

${ }^{44}$ Dean and Maiguashca, 'Gender, power and left politics', p. 398.
} 
tend to foreground its adverse effects. ${ }^{45}$ To understand the normative value of populist performance in a specific context, one must investigate what its participants are assembled for, how their performance works and what it does as a result. Some performances have the capacity to rupture the dominant discourses and power relations provided that 'the audience responds to an invitation to transformation and in so doing co-creates an alternative politics'. ${ }^{46}$ Rai suggests that performance 'can allow members of the group to be in a stage of reflection outside the normal boundaries of socially constructed and accepted rituals, facts, ideas and sentiments' ${ }^{47}$ The next section illustrates how the streets can be claimed by right-wing populist groups that enact their exclusionary collective identities and security discourses. As the section thereafter shows, however, these constructions of (in)security can be unsettled through feminist counterpopulist performances.

\section{The Independence March and the right-wing populist politics of (in)security}

What role does the assembly of bodies in the public space play in the populist construction of (in)security? In the Polish context, this question leads us to the annual mass rally - the March of Independence - that has served as a platform for the right-wing populist construction of (in)security. The march celebrates Poland's independence and is marked by mass attendance. For instance, the 2018 centenary march gathered around 250,000 participants. It was also the year when several representatives of the PiS government, including President Andrzej Duda, marched together with the participants in one gigantic spectacle. A sea of Polish flags, red flares lit in unison and the endless repetition of the national anthem by a massive crowd marching through the streets of the Polish capital -

\footnotetext{
${ }^{45}$ Alexandra Homolar and Georg Löfflmann, 'Populism and the affective politics of humiliation narratives', Global Studies Quarterly, 1:1 (2021), pp. 1-11.

${ }^{46}$ Rai, 'Political performance', pp. 1188-9.

${ }^{47}$ Ibid., p. 1187.
} 
the visual symbolism of the event is nothing less than spectacular. As Kotwas and Kubik observe, the march attracts large audiences with its immersive opportunities. ${ }^{48}$ Through different cultural rituals - specific handshakes, greeting each other with particular slogans, sharing food - the participants gain a stable identity and a sense of belonging to the imagined community.

What is peculiar about the march is that it has been symbolically dominated by far-right groups and their narrow vision of the identity of 'the Polish people' - white, Catholic, heteronormative and socially conservative. The march is organised by three radical nationalist groups (the National Radical Camp, the All-Polish Youth and the National Movement), all of which trace their roots back to fascist and anti-Semitic groups active in the interwar period. The march has been a meeting space for ultranationalists, who parade in unison and chant racist slogans, and aggressive football hooligans, who vandalise the streets and attack their opponents. Neo-fascist insignia and white supremacist banners are a constant feature of the marches. Claiming to march with 'the people', Poland's leaders - the Polish president and politicians from PiS - thus, marched side by side with far-right groups.

The performance of 'Polishness under threat' and its simultaneous defence draw on an exclusionary discourse of security with a masculine aesthetic. In 2013, groups participating in the march set on fire the LGBTQ+ Rainbow Arch to express their resistance to LGBTQ+ groups. The 2017 march was remembered for a massive installation depicting Islam as a Trojan Horse with the inscription 'Europe, wake up'. The slogan for the 2016 event was 'Poland, the Bastion of Europe', symbolising the rightwing mythology in which Poland appears as a defender of Europe against Islamisation and immigration. 'We go to the march to fight for our country, religion and honour [...]

\footnotetext{
${ }^{48}$ Marta Kotwas and Jan Kubik, 'Symbolic thickening of public culture and the rise of right-wing populism in Poland', East European Politics and Societies and Cultures, 33:2 (2019), pp. 435-71.
} 
because a culture (światopoglad) war is happening in Poland' - underlined Tomasz in an interview, representing one of the nationalist groups responsible for organising the march. ${ }^{49}$ These affectively laden performances have served to construct collective identities by enacting security narratives about the need to defend ethnic and cultural homogeneity against 'Europe as a civilisation of death [...] that is financed by [George] Soros and big businesses from the West'. 50

The 2020 march was organised under the motto 'Our civilisation, our rules', signifying a fight against the attacks on Poland, its people and culture. The main advertising poster pictured a knight using a sword to shatter a red-and-rainbow-coloured star, referring to the threat posed by communism and the LGBTQ+ community. ${ }^{51}$ The main target of the 2020 march was the pro-choice demonstrations which had begun several weeks earlier. Speaking in support of the near-total abortion ban, Robert Bakiewicz, the head of the association organising the march, said that 'what will remain of today's independence march [...] is a desire to show that we are a state or a society [...] which relates to these traditional, conservative, Christian, Catholic values' ${ }^{52}$ One of the symbolic acts through which participants tried to 'safeguard' the Polish nation was an arson attempt. It happened as some participants threw flares at a balcony displaying rainbow flags and the Women's Strike banners, causing one apartment to catch fire. ${ }^{53}$ Through such embodied performances of hypermasculinity, right-wing populist actors have shaped the contours of the identity of 'the people', securing it against imaginary

\footnotetext{
${ }^{49}$ Interview with Tomasz, member of the All-Polish Youth from Warsaw, 19 July 2019.

${ }^{50}$ Interview with Pawel, member of the National Radical Camp from Warsaw, 16 July 2019.

${ }^{51}$ Robert Bąkiewicz, Twitter post (2 November 2020), available at: \{https://twitter.com/RBakiewicz/status/1323211751287066631\} accessed 27 April 2021.

${ }^{52}$ Robert Bakiewicz quoted in 'Far-right Polish Independence Day march draws thousands despite ban', Reuters (11 November 2020), available at: \{https://www.reuters.com/article/us-polandindependence-march-idUSKBN27R2PY\} accessed 27 April 2021.

${ }^{53}$ Democ., $\quad$ Twitter post (11 November 2020), available at: \{https://twitter.com/democ_de/status/1326529502046941184\} accessed 27 April 2021.
} 
enemies. The analysis of the Independence March sheds light on the role of populist public assemblies in fostering conflictual behaviour towards various threatening Others and enabling a radical departure from established global norms concerning gender equality.

As far-right rallies have grown in numbers and acquired high visibility, PiS has been eager to rally nationalist passions in support of its claims to protect 'the people' from their imagined enemies. State officials joining the march have not attempted to change its symbolic message and make it more inclusive to those who do not share their exclusionary and menacing view of Polish national identity. ${ }^{54}$ The government has no issue with empowering the organising groups to set the tone for the Independence March and determine its meaning so long as this plays into its broader populist security discourse. There is deliberate ambiguity in the official response to the violence and explicit racism committed by the members of these groups. Without openly endorsing the agenda of the ultranationalist groups, PiS capitalises on the fears they spread about the dangers of multiculturalism and 'gender ideology'. Such 'strategic use of the far right', as Pasieka put it, is intended to capture the energy and sentiments that the far right effectively mobilises. ${ }^{55}$

The performance of (in)security on National Independence Day rests on a highly gendered discourse of ontological security about the loss of Polish national identity. Sexual and reproductive rights are portrayed as cultural weapons that global liberal elites employ against traditional Christian societies. 'Gender movements threaten our identity, threaten our nation, threaten the Polish state' - said Jarosław Kaczyński, the chairman of

${ }^{54}$ Kotwas and Kubik, 'Symbolic thickening'.

${ }^{55}$ Agnieszka Pasieka, 'Who is afraid of fascists? The Polish Independence March and the rise of the (far?) right', FocaalBlog (12 December 2018), available at: \{www.focaalblog.com/2018/12/12/who-isafraid-of-fascists-the-polish-independence-march-and-the-rise-of-the-far-right $\}$ accessed 14 August 2021. 
PiS. ${ }^{56}$ Consequently, nearly 100 Polish municipalities have passed resolutions declaring themselves 'LGBT-ideology-free zones', leading the European Commission to open an infringement procedure against Poland. Framing 'gender ideology' as a threat allows right-wing populists to glue together various issues attributed to the liberal agenda, including reproductive rights, LGBTQ+ rights and gender studies. ${ }^{57}$ Moral and biological decay is claimed to be the result of external efforts coming from the West to undermine national sovereignty and destroy the 'healthy body' of the Polish nation. By utilising these conspiracy narratives already circulating among right-wing groups, populist leaders have effectively portrayed themselves as the 'heroic defenders' of 'the true people'.

The ontological security discourse of PiS presupposes a deeply biopolitical conception of national identity. Grzebalska and Petö elucidate that PiS practises 'familialism' - that is, 'a form of biopolitics which views the traditional family as a foundation of the nation and subjugates individual reproductive and self-determination rights to the normative demand of the reproduction of the nation' ${ }^{58}$ The construction of 'the people' has involved various biopolitical and corporeal practices, turning otherwise private issues of reproductive behaviour and sexuality into matters of security and state control. ${ }^{59}$ The idea of protecting children's lives through strict abortion laws is central to the PiS discourse about the need to defend the collective national body against the influence of Western liberal values. Hence, Kaczyński's response to the pro-choice protests against the near-total abortion ban was to proclaim them a threat to the Polish

\footnotetext{
${ }^{56}$ Jarosław Kaczyński quoted in 'LGBTQ rights an import that threatens nation, Polish leader says', NBC News (25 April 2019), available at: \{https://www.nbcnews.com/feature/nbc-out/lgbtq-rightsimport-threatens-nation-polish-leader-says-n998436\} accessed July 18, 2021.

${ }^{57}$ Weronika Grzebalska and Andrea Pető, 'The gendered modus operandi of the illiberal transformation in Hungary and Poland', Women's Studies International Forum, 68:May-June (2018), pp. 164-72.

${ }^{58}$ Ibid., 167.

${ }^{59}$ Andrey Makarychev and Alexandra Yatsyk, 'Biopolitics and national identities: Between liberalism and totalisation', Nationalities Papers, 45:1 (2017), pp. 1-7.
} 
nation, calling on right-wing groups to 'defend Poland'. ${ }^{60}$ The aim of the protestors was allegedly 'to destroy Poland' and bring about 'the triumph of the forces whose power would, in fact, end the history of the Polish nation as we have seen it so far' ${ }^{61}$ This explains how the issue of abortion became an existential question of security for PiS, and why the feminist struggle for reproductive rights necessitated counteracting the conception of security at stake in right-wing populism.

\section{The Women's Strike: Feminist resistance}

Having examined how the right-wing populist performance of (in)security works in the Polish context, the paper moves to the discussion of feminist resistance. I argue that the Women's Strike movement has not been simply 'anti-populist'. Instead, it has actively employed the tool of populist performance and the language of (in)security but in a manner disruptive of right-wing populism. Exploring feminist counter-populist performances during the 2020-1 protests is crucial to understand how the populist aesthetics and discourses differ across the two competing performances of (in)security in the struggle to define 'the people' as the referent of security.

Scholars have thus far identified two main factors that disclose the presence of populist elements in the Polish pro-choice movement. First, the movement participants have tended to position themselves as 'ordinary women' fighting for the rights of all Polish people, but particularly the marginalised groups. ${ }^{62}$ 'We, the people of Poland, we stand' - declared the Women's Strike leading figure, Marta Lempart, while addressing

\footnotetext{
${ }^{60}$ Jarosław Kaczyński quoted in 'Oświadczenie prezesa PiS, wicepremiera Jarosława Kaczyńskiego’, (27 October 2020), available at: \{http://pis.org.pl/aktualnosci/oswiadczenie-prezesa-piswicepremiera-jaroslawa-kaczynskiego $\}$ accessed 27 April 2021.

${ }^{61}$ Ibid.

${ }^{62} J e n n i f e r$ Ramme and Claudia Snochowska-Gonzalez, '(Nie)zwykłe kobiety: Populizm prawicy, wola ludu a kobiecy suweren', in Elżbieta Korolczuk et al. (eds), Bunt Kobiet (Gdansk: Europejskie Centrum Solidarności, 2019), pp. 83-117 (pp. 99-100).
} 
the European Parliament. ${ }^{63}$ The 2020-1 demonstrations were defining for the movement because they prompted it to include a broader range of intersectional demands beyond reproductive rights. The demonstrations quickly adopted broader anti-government slogans, demanding LGBTQ+ rights, the restoration of judiciary independence, an end to the teaching of religion in schools and support for entrepreneurs, workers and people with disabilities. ${ }^{64}$ The inclusionary articulation of collective identity - in rejection of the rightwing populist vision of 'the people' - proved effective in mobilising broad layers of the population. Feminist groups were joined by various groups upset with the government and its policies, such as disabled people, miners, taxi drivers and farmers. ${ }^{65}$ The prochoice movement thereby began symbolising a broader popular struggle for freedom, democracy and human rights against the ruling elite.

The second reason why the movement can be considered as an instance of populist feminism is its tendency to reiterate the people-versus-elite dichotomy. Graff noted that the movement does not necessarily have a single 'feminist' identity, mobilising people around 'a common threat and a common enemy: ultra-conservative Catholics supported by the populist right-wing government'. ${ }^{66}$ In an interview, Teresa from Wroclaw described 'the elite' as a 'network of wealthy and influential fanatics from politics and civil society that have mobilised to destroy the health and lives of already marginalised women'. ${ }^{67}$ The anti-elite sentiment was also manifested in the attempts of the movement

\footnotetext{
${ }^{63}$ Marta Lempart, 'LIBE - FEMM Joint meeting' (24 February 2021), available at: \{https://multimedia.europarl.europa.eu/en/libe-femm-joint-meeting_20210224-1345-COM MITTEE-LIBE-FEMM_vd?start=20210224125448\&end=20210224144117\} accessed 26 April 2021.

${ }^{64}$ All-Poland Women's Strike, Facebook post (1 November 2020), available at: \{https://www.facebook.com/ogolnopolskistrajkkobiet/posts/5319905698035385\} accessed 6 September 2021.

${ }^{65}$ Maria Wilczek, 'Miners, farmers and taxi drivers unite behind protests against Poland's abortion laws', The Times (27 October 2020) available at: $\{$ https://www.thetimes.co.uk/article/pro-choice-and-farright-protest-together-against-polands-abortion-laws-xk373px8q\} accessed 6 September 2021.

${ }^{66}$ Graff, 'Angry women', p. 241.

${ }^{67}$ Interview with Teresa, member of Gals for Gals Wroclaw, 10 July 2019.
} 
to distinguish itself from an 'elitist', Westernised version of feminism typically associated with academics, NGOs and educated, urban and middle-class women activists. According to Amelia from Warsaw, 'our goal is to make feminist issues mainstream, even if it's some kind of pop feminism'. ${ }^{68}$ Disassociating itself from the view of feminism as a sophisticated intellectual project, the pro-choice movement gave rise 'a feminism of the masses', as Gunnarsson Payne put it. ${ }^{69}$

In addition to the construction of the political subject of 'the people' in opposition to 'the elite', the performative approach to populism also requires us to probe the presence of the performative enactment of 'us in danger'. In what follows, I explore the plural and embodied performances of (in)security that performatively constituted 'the feminist people'. I argue that the pro-choice movement can, indeed, be described as 'populist' in this respect, but its aesthetic of security is directly opposed to - and even disruptive of right-wing populism.

\section{Performance, plurality and embodiment}

On 23 October 2020, over 400,000 people took to the streets of Poland under the banners of the Women's Strike to protest against a near-total abortion ban. ${ }^{70}$ The decision to prohibit pregnancy terminations in cases of severe and irreversible foetal impairment was issued by Poland's Constitutional Tribunal. The Tribunal's legitimacy is highly contested due to the reforms undermining its independence from the government. ${ }^{71}$ The ruling meant an effective ban on abortion, as foetal abnormality had previously constituted the

${ }^{68}$ Interview with Amelia, member of Gals for Gals from Warsaw, 19 July 2019.

${ }^{69}$ Gunnarsson Payne, "Women as "the people", p. 18.

${ }^{70}$ Marta Lempart, 'Marta Lempart on leading Poland's abortion rights protests', Financial Times (2 December 2020) available at: $\{$ https://www.ft.com/content/b6012449-0c11-419a-b439-6e3320f47e86\} accessed 12 July 2021.

${ }^{71}$ Marc Santora and Joanna Berendt, 'Poland overhauls courts, and critics see retreat from democracy', New York Times (20 December 2017), available at: \{https://www.nytimes.com/2017/12/20/world/europe/eu-poland-

law.html?action=click\&module=RelatedLinks\&pgtype=Article $\}$ accessed 1 September 2021 . 
legal grounds for $98 \%$ of legal abortions in Poland. Terminations are now legal only in cases of rape, incest and where the mother's life or health appears at risk. The mass demonstrations erupted in spite of the COVID-19 restrictions, under which all public assemblies were forbidden. Criticisms were being voiced that the government exploited the global health crisis and the nationwide lockdown to push through the legislation. ${ }^{72}$

The protests resembled a civic rebellion led by enraged women and Polish youth who organised marches, blockades, pickets and attacks on churches. Some people put Black Protest posters on their cars and blocked traffic in some of the busiest roundabouts and crossroads across the country. Brandishing the red lightning bolt symbol used by the leading 'Women's Strike' group, the protestors mainly targeted the house of PiS leader Jarosław Kaczyński in Warsaw and PiS party offices across the country. The focus then shifted to Catholic churches, as demonstrators disrupted Sunday Mass by staging sit-ins and holding pro-choice banners in front of the altar or by collectively walking out of church services. As a member of a pro-choice group said, if [the Church] insist[s] on entering our lives when they are not welcome, then we will enter their churches with abortion'. ${ }^{73}$ Aside from claiming physical public spaces (streets, churches, roads), a parallel common 'space' was created on social media. Social media enabled people in different locations to belong and act together, despite the inability to gather in the streets.

The peaceful public gatherings were soon interrupted by both uniformed and undercover police and far-right groups. The protestors were thrown to the ground, hit with batons and pepper-sprayed by the police, including the military gendarmerie deployed to

\footnotetext{
${ }^{72}$ International Planned Parenthood Federation, 'Polish ruling party exploits the current health crisis to undermine women and young people's safety' (14 April 2020), available at: https://www.ippfen.org/news/polish-ruling-party-exploits-current-health-crisis-undermine-women-andyoung-peoples-safety\} accessed 2 September 2021.

${ }^{73}$ Quoted in "Sex is not a crime": The women protesting Poland's new abortion law', The Guardian (13 November 2020), available at: \{https://www.theguardian.com/world/video/2020/nov/13/sexis-not-a-the-women-protesting-polands-new-abortion-law \} accessed 27 April 2021.
} 
disperse the gathering. ${ }^{74}$ On some occasions, the police forcibly pulled demonstrators out of the crowd and drove them in a van to an undisclosed police precinct. According to Lempart, what at first resembled a 'picnic' was later brutally crushed by the police. ${ }^{75}$ The police were joined by far-right activists who created vigilante patrols to confront the protestors. The mobilisation of nationalist groups came as a response to a call by Kaczyński to 'defend churches at any cost' after several churches had been defaced by protestors. ${ }^{76}$ As Krzątała describes, 'what began as a spontaneous block party - civil disobedience to the rhythm of disco music and dancing at roundabouts and intersections of major streets $-[\ldots]$ escalated into a horrifying spectacle of police brutality and vigilante violence of nationalist groups', ${ }^{77}$

The exposure to violence should not, however, be taken as a sign of weakness of the movement. According to Butler, 'strength is not quite the opposite of vulnerability', as the embodied performance of vulnerability can serve as a strategy of collective mobilisation. ${ }^{78}$ Lempart stated that 'we are being detained, we are being beaten up, we are teargassed. We put our bodies on the line, and we put our lives on the line'. ${ }^{79}$ Klementyna Suchanow, a Polish writer and Women's Strike activist, also pointed out that the violence inflicted on assembled bodies was by no means indicative of the

74‘Żandarmeria Wojskowa pomoże policji. Zarządzenie premiera’, Rzeczpospolita (26 October 2020), available at: \{https://www.rp.pl/Wojsko/201029457-Zandarmeria-Wojskowa-pomoze-policjiZarzadzenie-premiera.html $\}$ accessed 27 April 2021.

${ }^{75}$ Marta Lempart, 'Lempart o działaniach policji: Najgorsze jest to, jak strasznie kłamią co do praw obywatelskich. Nie tylko tchórze, ale i łgarze', Wyborcza (29 November 2020), available at: \{https://wyborcza.pl/7,162657,26559344,lempart-o-dzialaniach-policji-najgorsze-jest-to-jakstrasznie.html \} accessed 19 April 2021.

${ }^{76}$ Kaczyński, 'Oświadczenie prezesa PiS'.

${ }^{77}$ Zuzanna Krzątała, "'You will never walk alone" - Polish women strike back', Humanity in Action, available at: \{https://www.humanityinaction.org/knowledge_detail/you-will-never-walk-alonepolish-women-strike-back/\} accessed 27 April 2021.

${ }^{78}$ Butler, Performative Theory of Assembly, p. 151.

${ }^{79}$ Lempart, 'LIBE - FEMM Joint meeting'. 
government's power, in fact, undermining it by generating stronger resistance. ${ }^{80}$ In her words, when 'they [the state] show their brutal face, it strengthens us, because people unite when those in power use violence against citizens', whose only weapons are their bodies assembled in the street. ${ }^{81}$ The persistence of bodies in alliance, notwithstanding the violent attempts at their dispersal, called the legitimacy of the government into question precisely by exercising a right to assembly that did not in principle exist. ${ }^{82}$ The demonstration of vulnerability was a deliberate, corporeal form of performing insecurity that negated and delegitimised the unjust social order. Marlena, a Women's Strike member from Warsaw, jokingly said in an interview that the protestors even managed to 'invert' the government's lockdown order by forcing Kaczyński to 'lock himself down at his home surrounded by the police, while we were taking charge of the street' ${ }^{83}$

Since the emergence of 'the people' through the act of coming together depends on infrastructural conditions, the public domain had to be claimed by seizing the matter of material environments. This was done by 'renaming' squares, streets and roundabouts after women fighting for their rights, as activists hanged new street signs over the official ones, and by submitting petitions for a formal name change. In February 2021, the opposition-ruled council in Krakow even voted to name the area in front of the PiS local headquarters as 'Women's Rights Square'. By replacing the names of male historical figures, participants asserted women's right to be treated as citizens equal to those whom the right-wing populist discourse frames as the 'true' people. Another performance that aimed to challenge the right-wing populist takeover of Independence Day was organised by the Women's Strike on 28 November. Marking the $102^{\text {nd }}$ anniversary of Polish

\footnotetext{
${ }^{80}$ Klementyna Suchanow quoted in Anita Karwowska, 'Strajk Kobiet odtajnia tajniaków. Zbiera nagrania z protestów', Wyborcza (20 November 2020), available at: \{https://wyborcza.pl/7,162657,26530516,strajk-kobiet-odtajnia-tajniakow-zbiera-nagrania-zprotestow.html \} accessed 27 April 2021.

${ }^{81}$ Ibid.

${ }^{82}$ Butler, Performative Theory of Assembly, p. 83.

${ }^{83}$ Interview with Marlena, Women's Strike participant from Warsaw, 14 January 2021.
} 
women's suffrage, this day was announced by the group to be an alternative Independence Day. In so doing, a national holiday that had been strongly reserved for the Polish right and its 'people' was reclaimed in the name of 'all of us', 'the feminist people'. As one of the leaders of the Warsaw Strike group Agnieszka Czerederecka asserted, 'Poland is a woman, so we will have a national holiday on that day'. ${ }^{84}$

The paper has now explored how the collectivity of 'the feminist people' was enacted through the acts of assembling, moving and fighting together. Analysing how everyday actors reappropriate the right to speak in the name of 'the people' is crucial to understanding how the global rise of right-wing populism encounters resistance in local contexts. It is now worth reflecting on the aesthetic the populist feminist performances carried, as it served as a vehicle for contesting the exclusionary imaginaries of (in)security.

\section{The populist feminist aesthetic of security}

In her analysis of the populist securitising style, Kurylo describes the right-wing populist aesthetic of security as deliberately 'simple-minded, inexpert, shallow, improper, antagonistic, emotional and irrational'. ${ }^{85}$ She demonstrates that populism seeks to be transgressive of the 'high' aesthetic of security that is practised by traditional security elites (politicians, technocrats, experts). Populists are shown to enact insecurity with the help of affective spectacles that are animated by inappropriateness, sentimentality and obtuseness. Pandering to the taste of the masses, the populist aesthetic rests on 'formulaic, banal and simplified motifs, emotions and themes' that reduce the complexity of security

${ }^{84}$ Agnieszka Czerederecka quoted in Anita Karwowska, 'Grudzień będzie gorący. Jak zawsze w ostatnich latach. Mamy nadzieję, że to koniec tej władzy', Wyborcza (20 November 2020), available at: \{https://wyborcza.pl/7,162657,26531798, grudzien-bedzie-goracy-jak-zawsze-w-ostatnich-latachmamy.html \} accessed 27 April 2021.

${ }^{85}$ Kurylo, 'Discourse and aesthetics of populism', p. 13. 
issues. ${ }^{86}$ The populist aesthetic, therefore, celebrates those features that are considered as aesthetic deficiencies in the eyes of 'the elite'.

Importantly, however, any claims about what the populist aesthetic of security is like must account for its context-dependent nature. The task of the analyst is to be attentive to how the context predisposes populist actors towards particular aesthetic representations of 'the endangered people'. It is essential to investigate how the populist aesthetic of security changes depending on the type of populism, its audience and the nature of 'the elite'. In Kurylo's study, for example, 'the elite' is mainly composed of traditional security actors, whose authority is being challenged by right-wing populist outsiders that seek to discredit rationality and expert knowledge. ${ }^{87}$ In contrast, what is distinct about the Polish context is that 'the elite', which the pro-choice movement targeted, was already from the register of right-wing populism. Thus, as illustrated below, the feminist performances during the 2020-1 protests encompassed many of the aforementioned populist aesthetic elements, but there were also some contextual differences. For example, far from trying to discredit scientific knowledge, pro-choice groups actively appealed to science when explaining why a pharmacological abortion is safe and when trying to debunk the anti-choice portrayal of abortion as the 'murder of unborn children'.

The populist feminist aesthetic of security was directly aimed at destabilising the representations of (in)security associated with the Polish right. One of the ways through which pro-choice groups sought to unsettle the norms of the 'elitist' aesthetic of security was an 'inappropriate' recontextualisation of national symbols previously reserved for the Polish right alone. Graff observes the tendency of the pro-choice movement to hijack symbols of national identity, treating them as a source of ideas for memes and giving

${ }^{86}$ Ibid., p. 15

${ }^{87}$ Ibid., p. 7. 
them new meanings. ${ }^{88}$ For instance, taking the symbols of the anti-communist Solidarity movement (1980-89) out of the context of Catholic patriotism, the movement participants made a new version of the iconic Solidarity poster from the 1989 election. The original poster featured Gary Cooper from the classical western High Noon wearing a Solidarity badge on his chest and armed with a ballot in place of a gun with the Solidarity logo appearing in the background. ${ }^{89}$ In the new version, the poster featured iconic women protagonists, such as Angelina Jolie from the action film Lara Croft, who were armed with weapons against the background of the Women's Strike emblem and its slogan: 'This is war. Fuck off!' ${ }^{90}$ The improper recontextualisation of such symbols was a means of destabilising the right-wing populist hold over the meaning of national identity and contesting the exclusionary terms of belonging.

As the analysis of the Independence March already revealed, the right-wing populist aesthetic of security is heavily focused on exhibiting heroism and strength as a means of defending the identity of 'the people'. ${ }^{91}$ In comparison, the Women's Strike protestors were unafraid to display the shared condition of vulnerability and exposure. For instance, a photograph by the Polish-born artist and filmmaker Iness Rychlik was circulating social media showing a woman holding a wire coat hanger with her groin area covered in blood..$^{92}$ The symbolic use of metal hangers puts the present struggle for

\footnotetext{
${ }^{88}$ Agnieszka Graff, 'Claiming the shipyard, the cowboy hat and the anchor for women: Polish feminism's dialogue and struggle with national symbolism', East European Politics and Societies and Cultures, 33:2 (2019), pp. 472-96.

${ }^{89}$ Ibid., p. 482.

${ }^{90}$ Jarek Kubicki, Facebook post (26 October 2020), available at: $\{$ https://www.facebook.com/photo/?fbid=10221508566575353\&set=pcb.10221500225686836 $\}$ accessed 27 April 2020.

${ }^{91}$ Ewa Majewska, 'Słaby opór i siła bezsilnych. \#Czarnyprotest kobiet w Polsce 2016' (10 November 2016), available at: \{https://www.praktykateoretyczna.pl/artykuly/ewa-majewska-saby-opor-isia-bezsilnych-czarnyprotest-kobiet-w-polsce-2016/ \} accessed 19 July 2021.

${ }^{92}$ Polish Masters of Art, Facebook post (30 October 2020), available at: \{https://www.facebook.com/PolishMastersofArt/photos/a.1526688624261610/2729223614008099\} accessed 27 April 2021.
} 
reproductive rights 'within a historical context where such items have been used to selfinduce abortion'. ${ }^{93}$ Some demonstrators could be seen carrying a figure of a crucified pregnant woman with red tears falling down her face. 'You have blood on your hands' read some of the placards at the protests, referring to the violence that the ruling elite has inflicted on women through its anti-gender policies. One banner depicted a woman sitting on a gynaecological examination chair with her legs spread wide and facing Kaczyński himself with the following note at the top: 'in the matter of giving birth, you have no say.${ }^{94}$ These dramatic visual representations were populist insofar as they used simplified and emotionally charged motifs to elicit immediate reactions from popular audiences.

There has been a noticeable shift in the aesthetic of the pro-choice movement since its earlier wave in 2016, known under the name of 'Black Protests'. The aesthetic of the Black Protests was associated with the images of crowds of women marching through the streets while being soaking wet and holding black umbrellas, signifying collective mourning for women's reproductive rights. ${ }^{95}$ In contrast, the feminist performances of 2020-1 were characterised by a more 'provocative' and 'vulgar' aesthetic. The fact that 'This is war' and 'PiS off' became the main chants and banner slogans of the protests was a result of the impossibility of women's voices being heard within the dominant security discourse. A video from the small town of Szczecinek captured a crowd of young women yelling at a priest to 'go back to church' and 'fuck off', with one woman shouting that 'in five years, it will be a sentence to be a woman living here!'. 96 The slogan 'We're granddaughters of witches who didn't burn' acted as a reminder that women used to be

\footnotetext{
${ }^{93}$ Gunnarsson Payne, "Women as "the people", p. 11.

${ }^{94}$ All-Poland Women's Strike, Facebook post (31 January 2021), available at: \{https://www.facebook.com/ogolnopolskistrajkkobiet/photos/pcb.5730873760271908/573087341693860 9/\} accessed 27 April 2021.

${ }^{95}$ Graff, ‘Angry women', p. 231.

${ }^{96}$ The video is available at: https://www.youtube.com/watch?v=49pBuXM4mYs.
} 
executed for 'witchcraft' until the $18^{\text {th }}$ century, simultaneously stressing women's resilience.

Vulgar humour played a crucial role in breaking the silence around taboo topics by aesthetically upsetting the norms of 'the establishment'. Hashtags such as \#AbortGovernment, \#AbortChurch and \#FuckPolishPatriarchy populated social media. Many slogans signified the determination of women to playfully reclaim their bodies from the control of the state and the Church: 'Stay out of my body', 'My belly is not a coffin', 'My vagina is an atheist', 'My pussy is not Yarek's [Jarosław Kaczyński's]' and 'Stop micromanaging my mating rituals'. 'It's a pity that Mary didn't have an abortion' - such inscription was painted on the wall of a church in Gliwice, which can be interpreted as a populist feminist demonstration of 'really bad taste'. ${ }^{97}$ In response to the criticisms about the vulgarity of the movement's aesthetic, the Women's Strike protestors unapologetically retorted with a new slogan: 'We kindly ask you to fuck off'. In an interview, one activist pointed out that provocative language and symbols expressed the 'anger and helplessness' that Polish women feel because 'the religious zealots ruling Poland took away our right to decide about our own bodies.${ }^{98}$

The emotions of rage and despair as well as solidarity and hope found expression through acoustic performative enactments, such as group-singing, chanting, screaming or shouting. A case in point is the song from the repertoire of the punk band Post Regiment which was re-recorded in support of the Women's Strike by the band called Mapa. Entitled 'When I Shout', the piece symbolises the angry scream of women whose voices have been silenced, and whose suffering has been rendered invisible: 'He wants to make

${ }^{97 ،}$ 'Szkoda, że Maryja nie zrobiła aborcji. Kolejny atak obrażający uczucia religijne’, TVP Info (26 October 2020), available at: \{https://www.tvp.info/50508346/protest-trybunal-konstytucyjny-aborcjagliwice-szkoda-ze-maryja-nie-zrobila-aborcji-kolejny-atak-obrazajacy-uczucia-religijne-wieszwiecej\} accessed 5 September 2021.

${ }^{98}$ Interview with Gabriela, member of the Women's Strike Klodzko, 11 February 2021. 
me obey, to intimidate, suppress, subjugate/ He will defile my most intimate matters, wants to kill me in myself ${ }^{99}$ The rest of the lyrics link the present-day struggle to women's historical experiences of gender-based violence, such as the mass rape during the Soviet occupation of Poland: 'I will be free from him, I will be free/ Cause I don't wanna be like my sisters, raped by soldiers, they gave birth to soldiers/ Obedient, silent, there was nothing they could do - not even think'. Screaming became a collective performative act signifying the determination of women to assert the right to decide about their bodies, which they have been historically denied.

The paper has now illustrated that feminist resistance to right-wing populism involved a vivid aesthetic dimension. The aesthetic of feminist performances of insecurity was populist insofar as they were 'easily digestible, visually arresting and thrilling in their tendency to say the unsayable'. ${ }^{100}$ Vulgar humour, emotionality and the deliberate subversion of social convention functioned as vehicles through which the protestors attempted to make claims to security in the face of its denial. On a more fundamental level, the embodied practices of resistance were essential for the self-constitution of 'the feminist people', whose subjectivity was marked by the shared condition of vulnerability and dependence. This aesthetically constituted subjectivity, in turn, gave birth to a related concept of (in)security that has appeared at the heart of the feminist counter-populist politics of security in Poland, which is the subject of the next section.

\section{Security, precarity and livable life}

How did pro-choice groups come to perceive the issue of reproductive health in security terms, and what did security mean in their counter-populist discourses? The issue of abortion was already constructed as a security question before the rise of the pro-choice

\footnotetext{
${ }^{99}$ The video is available at: https://www.youtube.com/watch?v=v3gde1BSmp8.

${ }^{100}$ Kurylo, 'Discourse and aesthetics of populism', p. 15.
} 
movement. In the right-wing populist discourse, abortion was depicted as an existential threat to 'conceived children with disabilities' and the continuity of Polish national identity. ${ }^{101}$ Consequently, the survival of the foetus and the needs of the nation were placed above the life, health and well-being of the woman. In trying to counter the rightwing populist construction of abortion as a problem of ontological and biopolitical security, feminist groups did not seek to 'desecuritise' the issue of abortion. Rather, they actively used the language of security in order to reclaim it for 'the feminist people'. While resistance did not bring the Women's Strike outside of the populist politics of security, the movement introduced a different understanding of security that was a direct antithesis to the right-wing populist one. This section will show that the pro-choice movement reconceptualised security in the more inclusionary logic of 'livable life'.

In my interviews with the Women's Strike participants, there was a clear sense that they viewed the near-total ban as a threat to women's security. According to Marlena from Warsaw, her engagement was motivated by the striving 'to make this country safe for women to live in'; in the name of 'our children, sisters, friends and ourselves'. ${ }^{102}$ Paulina, a protestor from Krakow, explained that 'we are forced to go through pregnancies that can be a potential danger to our lives'. ${ }^{103}$ She added that women are forced to seek abortion services at great personal risk: 'it is dangerous for women to get an abortion in the basement. Hangers stop being just a symbol... ${ }^{104}$ Zuzanna, an activist from Gdynia, remarked that 'we are subjected to torture by our own state', whose form of rule resembles 'a military dictatorship of religious zealots'. ${ }^{105}$ A similar message appeared on the Women's Strike Facebook page: 'our state institutions are being directed against us

\footnotetext{
2019.

${ }^{101}$ Interview with Michał, member of the Pro-Right to Life Foundation from Warsaw, 17 July

${ }^{102}$ Interview with Marlena, Women's Strike participant from Warsaw, 14 January 2021.

${ }^{103}$ Interview with Paulina, Women's Strike participant from Krakow, 12 February 2021.

${ }^{104}$ Ibid.

${ }^{105}$ Interview with Zuzanna, Women's Strike participant from Gdynia, 10 February 2021.
} 
instead of protecting us'. ${ }^{106}$ The question is no longer simply whether the state has failed at providing support to women in need of abortion; a better question is 'how can we protect ourselves against the state?' ${ }^{107}$

The participants were brought together by the recognition of the shared problem of precarity - or what Butler defines as a politically induced and differentially distributed condition of precariousness. ${ }^{108}$ Precarity designates a situation when certain groups in society suffer from failing social and infrastructural support networks, for which the law fails to provide sufficient redress. ${ }^{109}$ According to one interviewee, 'if you get pregnant and you're struggling, the state leaves you to fight for your life all on your own'. ${ }^{110}$ Poland is already believed to have one of the highest numbers of illegal abortions in Europe, with estimates lying between 120,000-150,000 per year, 'usually being either selfadministered medical abortions or illegal surgical terminations'. ${ }^{111}$ Modern contraceptive methods are also not freely available in Poland, with the morning after pill requiring a prescription and a consultation with a doctor. The new abortion law is likely to disproportionally affect the most vulnerable: women who already face economic and social deprivation, live in rural areas and cannot afford to travel abroad to have an abortion. The aim of the Women's Strike was, therefore, to position 'us, the feminist people' as the referent of security, showing that women's bodies are not disposable and require infrastructural conditions of living.

\footnotetext{
${ }^{106}$ All-Poland Women's Strike, Facebook post (25 November 2020), available at: \{https://www.facebook.com/ogolnopolskistrajkkobiet/posts/5429823133710307/\} accessed 16 April 2021.

${ }^{107}$ Interview with Giovanna, Women's Strike participant from Warsaw, 28 January 2021.

${ }^{108}$ Butler, Notes toward a Performative Theory of Assembly, p. 33.

${ }^{109}$ Ibid.

${ }^{110}$ Interview with Paulina, Women's Strike participant from Kraków, 12 February 2021.

${ }^{111}$ Federation for Women and Family Planning, 'Polish Constitutional Tribunal publishes justification for the abortion-banning ruling’, available at: \{https://en.federa.org.pl/polish-constitutionaltribunal-publishes-justification-for-the-abortion-banning-ruling/\} accessed 27 April 2021.
} 
Rather than being simply an existential condition of precariousness definitive for all women, the precarity of women denied reproductive health care is the flipside of the dominant right-wing conception of security. Asking 'whose lives count as lives?', Butler argues that the decision concerning who is recognisable as a subject deserving of state protection is made by excluding lives that are considered to be disposable. ${ }^{112}$ In Poland, the woman's right to living a meaningful life has been deemed surplus to the survival of 'children in the womb' and the needs of the Polish nation. Lena from Warsaw describes the extent to which the everyday life of women living in Poland is interminably precarious due to the restrictive reproductive health policies: 'I never wanted to have children. I realised that in order to survive in Poland as a woman, I have to get sterilised. [...] Nobody cares about the lives of those who get pregnant'. ${ }^{113}$ Rather than the concern with physical survival, however, her words refer to the need to preserve 'life' understood in broader terms.

This seconds Butler's argument that, when the infrastructural conditions of life are imperilled, it is impossible to have a 'livable life', a life without precarity. As she qualifies, 'one can survive without being able to live one's life' in the conditions where it may not even 'seem worth it to survive'. ${ }^{114}$ In Frames of War, Butler elucidates that the concept of 'life' can be understood differently in relation to abortion. ${ }^{115}$ Disavowing the focus on life as a minimum biological condition, she reconceptualises life as an interdependent and socially conditioned process that is possible only in the conditions that make it livable. From this standpoint, 'there is no life without the conditions of life that variably sustain life, and those conditions are pervasively social'. ${ }^{116}$ Given the

${ }^{112}$ Judith Butler, Precarious Life: The Powers of Mourning and Violence (London: Verso, 2004), p. 20.

${ }^{113}$ Lena, member of the Abortion Dream Team from Warsaw, 30 May 2021.

${ }^{114}$ Butler, Performative Theory of Assembly, p. 209.

${ }^{115}$ Judith Butler, Frames of War: When Is Life Grievable? (London: Verso, 2009)

${ }^{116}$ Ibid., p. 19. 
interdependent nature of life, there is a need for social, economic and political obligations to minimise precariousness and maximise the flourishing of life. ${ }^{117}$

The notion of 'livability' calls into question the focus on the survival of the foetus that is foregrounded in the right-wing populist discourses of security. The slogans appearing on the Women's Strike placards underscore that the ability to survive in the abstract is insufficient for a sustained life: 'We want to live, not just survive', 'Anti-choice is anti-life' and 'I am pro-life... the life of women'. This widens the scope of security to account for the conditions that humans require to live viably beyond mere persistence (i.e., staying alive), but what precisely this means is a matter of contextual judgement. Depending on circumstances, therefore, the inability to secure the conditions for a livable life may signal the need for access to abortion, for example, if a woman requires it to maintain her livelihood. As Eliza from Wroclaw put it, 'I'm not going to give up my life to raise children'. 118

A symbolic example of the feminist reclaiming of the meaning of life is the 'hijacking' of the image depicting a nine-month-old foetus inside the heart-shaped womb. ${ }^{119}$ The artwork was originally created by the Russian artist Ekaterina Glazkova only to be later used without her consent by the anti-choice campaign as its main symbol. After contacting the artist and receiving her support, activists from Klodzko's branch of the Women's Strike reappropriated the artwork in order to change its meaning. Instead of arousing a feeling of guilt for having an abortion, the image was now accompanied by messages simulating a compassionate conversation between a mother and her baby. Some of them read: 'Mummy, I'm gay. - That's ok, son. I'm lucky to have you. Love you'; 'Mum, what if I grow up and get pregnant? - You will do whatever you think is right,

\footnotetext{
${ }^{117}$ Kathryn McNeilly, 'From the right to life to the right to livability: Radically reapproaching "life" in human rights politics', Australian Feminist Law Journal, 41:1 (2015), pp. 141-59.

${ }^{118}$ Eliza, Gals for Gals Wroclaw, Wroclaw, 20 July 2019.

${ }^{119}$ Interview with Gabriela.
} 
sweetheart'; and 'Why are you crying, mummy. - [Because] you will be disabled and neglected by the state'. ${ }^{120}$

To be 'pro-life' was no longer synonymous with the protection of life in and of itself, signifying a call to bring about an egalitarian social and political order in which the flourishing of everyone's life could be possible. In a Facebook post from 14 January 2021, the Klodzko branch of the Women's Strike described a more comprehensive idea of life that extends beyond 'human birth'. Being 'pro-life' means that 'we are for our own lives and for the lives of our children [...] regardless of who they are'. Raising the issue of LGBTQ+ discrimination in the country, the group emphasised that one does not stop being worthy of 'life protection' after 'their coming out as a non-heteronormative person'. These examples suggest that the meaning of security was reoriented towards the goals of minimising the gendered distribution of precariousness and working towards broader social transformation.

Rethinking the meaning of security also implies rethinking the practices through which it is to be achieved. Butler argues that all humans are invariably dependent on each other for their safe and dignified existence, and livable life is not something one can enjoy in separation from others. ${ }^{121}$ The mindfulness of this inevitable dependency on others led the Women's Strike to make interdependency the basis of their claims to security construed as livable life. This is symbolised by the slogans such as 'You'll never walk alone' and 'When the state doesn't protect me, my sisters will'. Ada, a member of a feminist collective from Lodz, agrees that the main strength of the movement lies in 'selfcare' or the idea that 'women organise to help each other with abortions and prenatal

\footnotetext{
${ }^{120}$ Strajk Kobiet Kłodzko i Powiat, Facebook post (14 January 2021), available at: \{https://www.facebook.com/StrajkKobietKlodzko/photos/pcb.2879358735681771/2879358559015122\} accessed 27 April 2021.

${ }^{121}$ Butler, Precarious Life.
} 
care'. ${ }^{122}$ During the demonstrations, a vast number of street posters, placards and social media posts displayed the phone number of Abortion Without Borders. The latter is a recently formed transnational initiative that provides information, funding and logistical assistance to help women living in Poland travel abroad for abortion care or order medical abortion pills online. By establishing these relational networks of support to help people in unwanted pregnancies, the protestors were embodying an alternative meaning of security to the one they opposed.

This section has demonstrated that the concept of livable life captures the logic of security that propelled the counter-populist mobilisation of the Polish pro-choice movement. This is an essentially political concept that, within this context, became essential to the feminist reconstituting of security in consonance with the principles of reciprocity, equality and solidarity. Rather than proposing that all feminist articulations of security must be universally viewed through the lens of livable life, this paper expands the knowledge of how marginalised agents reinvent the meaning of security in contextually specific ways.

\section{Conclusion}

In her feminist critique, Maiguashca argues that the way the concept of populism is presently deployed by scholars 'does not bode well for feminists politically'. ${ }^{123}$ One of the reasons for this is the male-dominated state of the field that results in a narrow and problematic conceptualisation of populism based on the 'mapping [of] the prowess and antics of far-right male leaders and the quantification and de-coding of their speeches'.124 Consequently, populism research tends to be 'marred by anaemic conceptions of power, collective agency and subjectivity', failing to understand how collective struggles

\footnotetext{
${ }^{122}$ Interview with Ada, member of Gals for Gals Lodz, 15 June 2021.

${ }^{123}$ Maiguashca, 'Resisting the "populist hype", p. 769.

${ }^{124}$ Ibid., p. 784.
} 
emerge. ${ }^{125}$ Even when applying a gender lens to the study of populism, researchers too often accept this problematic conceptual baggage. In contrast, this paper has moved away from the common association of populism with personalistic leaders, passive publics and negative security logics. Butler's theory of embodied and plural performativity has helped to explain how the collective political subjectivity of 'the people' can arise as bodies gather in the public space to enact their right to security through both verbal and nonverbal means. The analysis of populist feminism further revealed the attempts of situated actors to reshape populism in a way that is more in congruence with feminist goals.

The case of Poland has given us insight into two contending populist performances of (in)security in the ongoing war over which 'people' deserve to be treated as the referent of security. On the one hand, right-wing groups have used the Independence March as a stage for performing an exclusionary identity of 'the people' and symbolically defending it against the so-called domestic and global liberal elite. On the other, we can see attempts by the Women's Strike to performatively destabilise the right-wing politics of security. By assembling together, the protestors exercised the performative power to assert the right to security which they had been denied. Butler argues that 'sometimes it is not a question of first having power and then being able to act' and articulate one's needs. ${ }^{126}$ Rather, concerted action has a performative effect of laying claim to the power one requires to 'act politically in order to secure the conditions of existence'. ${ }^{127}$ I have, therefore, argued that feminist resistance to the right-wing populist constructions of (in)security can inaugurate an alternative politics of security in the name of 'the feminist people'.

\footnotetext{
${ }^{125}$ Ibid., p. 772.

${ }^{126}$ Butler, Performative Theory of Assembly, p. 58.

${ }^{127}$ Ibid.
} 
The Polish case is significant because it is representative of a wider phenomenon of resistance mobilisation against right-wing populism and its gendered constructions of 'dangerous others'. Diverse solidarity movements are arising in various parts of the world that contest right-wing imaginaries of security. ${ }^{128}$ The Women's Strike continues the line of an enduring feminist movement on a transnational scale. Its participants are well-aware of this, as suggested by the fact that many protestors wore green handkerchiefs around their necks to demonstrate solidarity with the abortion-rights movement in Argentina, where a similar struggle was happening at the time. The paper has shown that resistance may sometimes involve employing the technique of populist performance of (in)security to express feminist or democratic demands. Yet, by virtue of this very act, resisting actors are creatively reinventing the identity of 'the people' in whose name they speak and reconceptualising security in order that it may better address their needs. In this case, embodying an alternative meaning of security as livable life, the Women's Strike sought to open the future to new social modes of existence, where the thriving of life could be possible.

The broader conclusion to be drawn from this analysis is that the relationship between populism, security and feminism cannot be deduced a priori but must be thoroughly contextualised to understand how it plays out differently in various settings. With the increasing engagement with populism in IR scholarship, there has been a temptation to make sweeping generalisations about vastly diverse cases and lump them together into a single monolithic understanding of populism. As Stengel, MacDonald and Nabers notice, 'the way populism is often understood in the IR literature makes it virtually useless for any differentiated analysis'. ${ }^{129}$ Here, the feminist interest in the situated

\footnotetext{
${ }^{128}$ Birte Siim, Anna Krasteva and Aino Saarinen (eds), Citizens' Activism and Solidarity Movements: Contending with Populism (Cham: Palgrave Macmillan, 2019).

${ }^{129}$ Frank Stengel, David MacDonald and Dirk Nabers, 'Introduction: Analysing the nexus between populism and International Relations', in Frank Stengel, David MacDonald and Dirk Nabers (eds),
} 
experiences of women makes it imperative to attend to how populism is actually enacted by agents on the ground and what security means to them. One should refrain from establishing a master narrative of how populists construct (in)security and the implications this has for feminist politics. More bottom-up contextual analyses are needed to explore how a plethora of grassroots agents come together under a collective 'we' to lay claim to security, bringing new subjectivities into being. After all, in some instances, populism may well create unexpected openings for the empowerment of marginalised actors and the discovery of new forms of cohabitation that better meet people's security needs.

Acknowledgements. I would like to gratefully thank the three anonymous reviewers, the editorial team of Review of International Studies, Felix Ciută and Ursula Woolley for taking the time to provide such incisive feedback on various iterations of this article.

Biography: Bohdana Kurylo is a PhD candidate in the School of Slavonic and East European Studies at University College London. She is a recipient of the Victor and Rita Swoboda Memorial Scholarship, the Overseas Research Scholarship and the SSEES Excellence Scholarship. Her research explores the role of civil society in the politics of security in Poland and Ukraine. Her most recent article explored the populist style of securitisation and was published in International Relations.

Populism and World Politics: Exploring Inter- and Transnational Dimensions (London: Palgrave, 2019), pp. 1-22 (p. 4). 